\title{
Regression of Basal Cell Carcinoma by Intralesional Interferon-alpha Treatment Is Mediated by CD95 (Apo-1/Fas)-CD95 Ligand-induced Suicide
}

\author{
Stanislaw A. Buechner, ${ }^{\star}$ Marion Wernli, ${ }^{\ddagger}$ Thomas Harr, ${ }^{\ddagger}$ Sinuhe Hahn, ${ }^{\ddagger}$ Peter Itin, ${ }^{\star}$ and Peter Erb ${ }^{\ddagger}$ \\ $*$ Department of Dermatology, University of Basel, Kantonsspital, Petersgraben 4, CH4031 Basel, Switzerland; and ${ }^{\ddagger}$ Institute for Medical \\ Microbiology, University of Basel, Petersplatz 10, CH-4003 Basel, Switzerland
}

\begin{abstract}
Basal cell carcinoma (BCC) is the most common skin cancer in humans, and although metastasis rarely occurs, the tumor cells are nevertheless able to invade and destroy the surrounding tissue. Intralesional injection of IFN-alpha has been found to be highly effective in inducing BCC regression by an unknown mechanism. We show that in untreated patients, BCC cells express CD95 ligand, but not the receptor, which may allow tumor expansion by averting the attack of activated CD95 receptor-positive lymphoid effector cells. The CD95 ligand of BCC cells is functional as CD95positive cells incubated on BCC cryosections become apoptotic and are lysed. In IFN-alpha-treated patients BCC cells express not only CD95 ligand but also CD95 receptor, whereas the peritumoral infiltrate that mainly consists of CD4 + $T$ cells predominantly contains CD95 receptor and only few CD95 ligand-positive cells. Thus, in treated patients BCC most likely regresses by committing suicide through apoptosis induction via CD95 receptor-CD95 ligand interaction. (J. Clin. Invest. 1997. 100:2691-2696.) Key words: basal cell carcinoma - apoptosis - CD95 - CD95 ligand • IFN-alpha
\end{abstract}

\section{Introduction}

Results from several clinical trials suggest that interferon is effective in the treatment of basal cell carcinoma $(\text { BCC })^{1}(1-9)$. Using intralesional IFN-alpha over a 3-wk period the overall success rate in most trials was between 70 and $100 \%(3,10)$. The mechanism by which intralesional IFN-alpha produces regression of $\mathrm{BCC}$ is not clear. Interferons are a group of naturally occurring glycoproteins that possess multiple biological effects including the control of cell growth and differentiation, regulation of cell surface antigen expression, and modulation of humoral and cellular immune responses (11-13). The fact that a considerable increase in the number of CD4+ T cells infiltrating the dermis and surrounding the BCC nests was observed after intralesional IFN-alpha therapy has been interpreted to indicate that this $\mathrm{T}$ cell subset is involved in

Address correspondence to Peter Erb, Institute for Medical Microbiology, University of Basel, Petersplatz 10, CH-4003 Basel, Switzerland. Phone: +41 6126732 62; FAX: +41 6126732 98; E-mail: Erb@ubaclu.unibas.ch

Received for publication 20 March 1997 and accepted in revised form 16 September 1997.

1. Abbreviation used in this paper: $\mathrm{BCC}$, basal cell carcinoma.

J. Clin. Invest.

(C) The American Society for Clinical Investigation, Inc. 0021-9738/97/12/2691/06 \$2.00

Volume 100, Number 11, December 1997, 2691-2696

http://www.jci.org triggering the immune response against tumor cells $(2,13,14)$. Both CD4+ and CD8+ T cell subsets can express cytolytic activity against a variety of target cells, including tumor cells, by inducing apoptosis (15-17). Apoptosis is characterized by nuclear and cytoplasmic condensation of single cells with dense aggregates of chromatin lining the nuclear membrane, followed by loss of the nuclear membrane and fragmentation of the nuclear chromatin, resulting in formation of multiple membrane-bound apoptotic bodies (18-20). Recently, it has been shown that CD4+ cytotoxic T cells are capable of inducing apoptosis in their target cells via CD95 receptor-CD95 ligand interaction (21-24). CD95 receptor (CD95), a cell surface molecule belonging to the TNF receptor superfamily, is expressed on a variety of cell types, whereas CD95 ligand (CD95L), a member of the TNF family, is predominantly expressed on activated $\mathrm{T}$ cells (25). Thus, it is conceivable that after intralesional treatment with IFN-alpha, infiltrating cytotoxic lymphocytes destroy BCC cells by CD95-CD95L interaction. Surprisingly, we found that BCCs commit suicide upon intralesional IFN-alpha treatment by concomitant expression of CD95 as well as CD95L.

\section{Methods}

Patients. 15 patients with histologically proven nodular BCC participated in the study. Nine patients were treated with IFN-alpha, whereas six patients served as controls and remained untreated. After informed consents were obtained, lesions were injected with recombinant IFN-alpha $2 \mathrm{~b}$ (supplied as a lyophilized powder containing $3 \times$ $10^{6} \mathrm{IU}$; INTRON-A, Essex Chemie AG, subsidiary of ScheringPlough Corp., Kenilworth, NJ). Each vial was diluted with $1 \mathrm{ml}$ preservative-free sterile water. Six patients received $1.5 \times 10^{6} \mathrm{IU}$ of IFNalpha three times a week for $3 \mathrm{wk}$, for a total dose of $13.5 \times 10^{6} \mathrm{IU}$. Two patients received $3.0 \times 10^{6} \mathrm{IU}$ per injection three times weekly with a cumulative dose of $27.0 \times 10^{6} \mathrm{IU}$, and another patient was treated with three injections of $1.5 \times 10^{6} \mathrm{IU}$ given in $1 \mathrm{wk}$. Seven of the nine patients were completely cured 6 wk after completion of the therapy. In two patients the result of the therapy could not be evaluated as the tumors were excised at the end of the therapy.

Skin biopsy specimens. Skin biopsy specimens were obtained from lesional skin at the end of treatment from two patients. In one patient biopsy was performed $1 \mathrm{wk}$ after completion of the therapy, and six patients had skin biopsies 14 to $21 \mathrm{~d}$ after treatment. Excisional biopsies from six untreated patients with nodular BCCs served as controls. All tissue specimens were snap-frozen in liquid nitrogen and used for immunohistochemical staining and for in situ apoptosis detection.

Immunohistochemistry. The monoclonal antibodies used were CD3, CD4, CD8 (Dako SA, Glostrup, Denmark), and anti-CD95 (Medical \& Biological Laboratories Co. Ltd., Nagoya, Japan). A polyclonal anti-CD95L-peptide antibody has been prepared in rabbits. The peptide selected according to Tanaka et al. (26) was synthesized and coupled via cysteine to maleide-activated keyhole limpet hemocyanin or ovalbumin (KLH-CD95L; OVA-CD95L) using the Imject Activated Immunogen Conjugation Kit (Pierce, Rockford IL). A rabbit was intramuscularly injected with $500 \mu \mathrm{g}$ KLH-CD95L emulsified in complete (for the first injection) or incomplete Freund's 

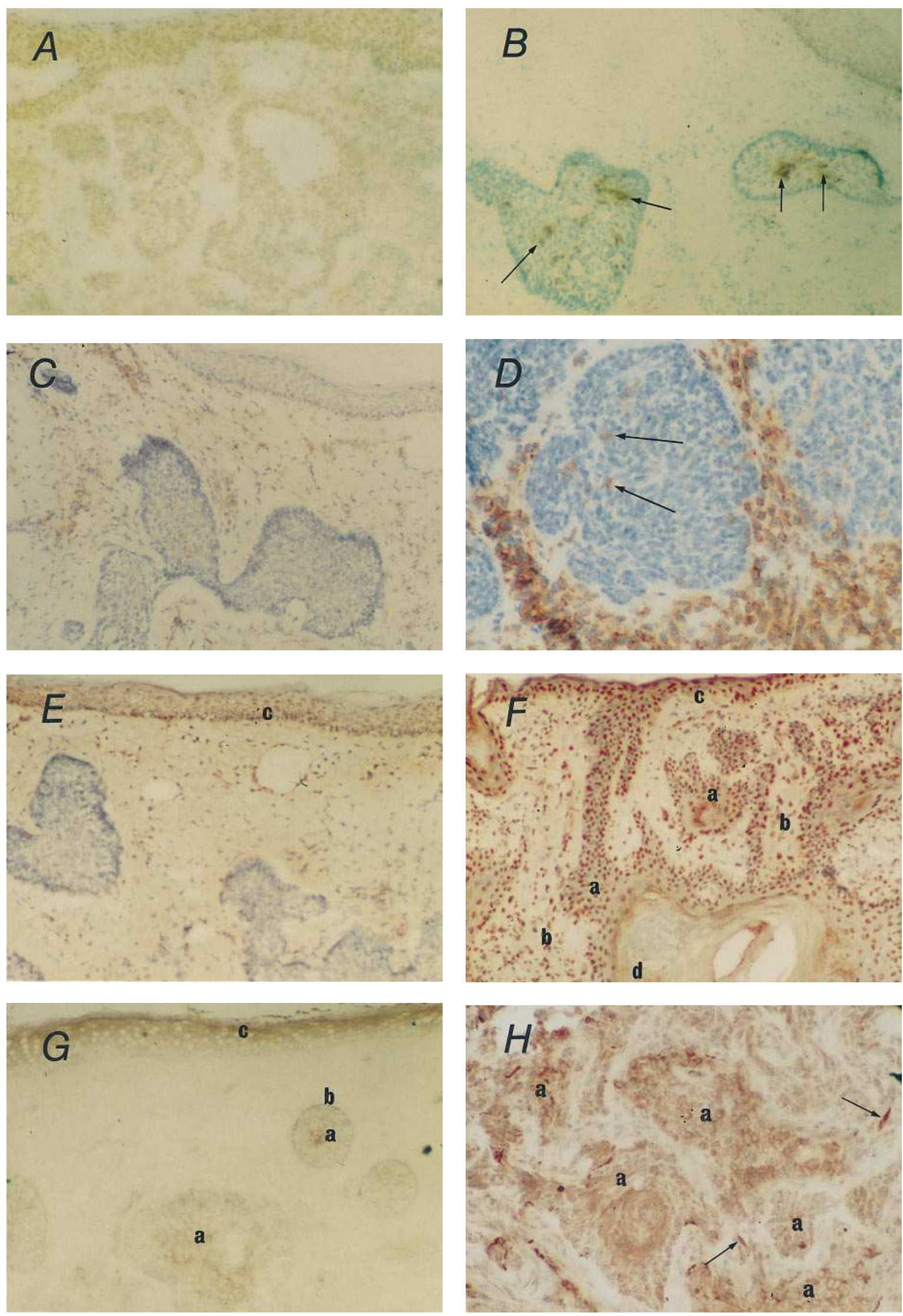

Figure 1. Apoptosis, expression of CD4, CD95, and/or CD95-ligand in BCC of IFN-alpha-treated or -untreated patients. ( $A, C$, $E$, and $G)$ Untreated patients; $(B, D, F$, and $H)$ IFN-alpha-treated patients. $(A)$ No apoptosis is found in BCC of untreated patients. $(B)$ Apoptotic cells $($ dark brown) are found in the center of the tumor nests (arrows) of IFN-alpha-treated BCC. (C) A sparse lymphoid infiltrate consisting of CD4+ 
adjuvant four times at three weekly intervals. Blood collection was done $7 \mathrm{~d}$ after the last injection. The serum obtained was affinity-purified over OVA-CD95L coupled to CNBr sepharose (Pharmacia Biotech, Dübendorf, Switzerland) or over CD95L peptide bound to Ultralink iodoacetyl matrix (Pierce, Rockford, IL). The specificity of the purified antibody was assayed in enzyme immunoassays using soluble human CD95L (Alexis Corporation, Läufelfingen)-coated plates on CD95L-positive cell lines (Jurkat, HUT) by immunoperoxidase staining, Western blots, and cytofluorography.

The immunohistochemical staining procedure used involving the monoclonal antibodies was the labeled streptavidin-biotin technique (Dako Diagnostics AG, Zug, Switzerland). Frozen specimens were cut in $6 \mu \mathrm{m}$-thick cryostat sections, air-dried, and fixed in acetone for $10 \mathrm{~min}$ at $-20^{\circ} \mathrm{C}$. Sections were then incubated for $30 \mathrm{~min}$ at room temperature with a primary murine monoclonal antibody at a concentration of 1:100. Endogenous peroxidase activity was blocked by incubation with $0.6 \%$ hydrogen peroxide in methanol. The sections were subsequently incubated with biotinylated goat anti-mouse Ig as secondary antibody at a concentration of 1:100 for $25 \mathrm{~min}$. After washing in Tris- $\mathrm{HCl}$ buffer, the sections were incubated with peroxidase-conjugated streptavidin (1:100) as a third reagent for $25 \mathrm{~min}$. Peroxidase activity was visualized using 3-amino-9-ethyl carbazole solution (AEC substrate-chromogen; Dako Diagnostics AG) according to the manufacturer's instruction. Finally, sections were gently washed with distilled water, counterstained with haematoxylin, and mounted under glass coverslips. In each case and for each antibody, omission of the primary antibody was used as a negative control. For staining with the anti-CD95L antibody, acetone-fixed sections were preincubated in PBS containing $10 \%$ goat serum at $37^{\circ} \mathrm{C}$ for $30 \mathrm{~min}$. Sections were then incubated with the affinity-purified anti-CD95L at a concentration of 1:15 at room temperature for $1 \mathrm{~h}$, washed in PBS, and incubated either with a 1:200 dilution of peroxidase-conjugated goat anti-rabbit IgG (Sigma Chemie AG, Buchs, Switzerland) at room temperature for $30 \mathrm{~min}$, or with biotinylated goat anti-mouse Ig followed by peroxidase-conjugated streptavidin as described above. As control, the prebled serum of the same rabbit used for the production of anti-CD95L was used at the same concentration.

Terminal deoxynucleotidyl transferase-mediated dUTP nick end labeling (TUNEL). The Apop Tag (Oncor Inc., Gaithersburg, MD) in situ apoptosis detection kit or the In Situ Cell Death Detection Kit (Boehringer Mannheim, Mannheim, Germany) was used according to the manufacturer's instructions. In brief, tissue cryosections were fixed in formalin for $10 \mathrm{~min}$, washed, and post-fixed in a 2:1 mixture of ethanol and acetic acid for $5 \mathrm{~min}$ at $-20^{\circ} \mathrm{C}$. Endogenous peroxidase was blocked in $2 \%$ hydrogen peroxide. After rinsing and applying equilibrium buffer, TdT enzyme was added and incubated at $37^{\circ} \mathrm{C}$ for $1 \mathrm{~h}$. Stop/wash buffer was then added for $10 \mathrm{~min}$, and antidigoxigenin peroxidase was applied for $30 \mathrm{~min}$. Color development was done using $\mathrm{DAB}$ substrate solution, and counterstaining was performed using methyl green. As negative controls, the slides were prepared in the same way except that TdT enzyme was omitted. As positive control, an IL-3 dependent mastocytoma cell line was used, which becomes rapidly apoptotic upon IL-3 removal. The Boehringer kit was used in a similar protocol except that after blocking endogenous peroxidase the slides were permeabilized with $0.1 \%$ Triton, and fluorescein-dUTP was used to label DNA strand breaks.
Demonstration of functional CD95L. Cryosections were prepared from IFN-treated and untreated BCC as well as from healthy skin, and were transferred onto siliconized glass slides. CD95-positive cells $\left(4 \times 10^{5} \mathrm{~A} 20.2 \mathrm{~J}\right)$ were seeded on each cryosection in a half-andhalf mixture of Iscove's modified Dulbecco's medium containing 5\% FCS and keratinocyte-SFM medium (Life Technologies AG, Basel, Switzerland). After $6 \mathrm{~h}$ the cells were harvested, washed with PBS, fixed in $70 \%$ ethanol for $1 \mathrm{~h}$ at $-20^{\circ} \mathrm{C}$, and stained with propidium iodide $(50 \mu \mathrm{g} / \mathrm{ml})$ for $15 \mathrm{~min}$ at $37^{\circ} \mathrm{C}$. Quantitative analysis of apoptosis was performed by FACScan (Becton Dickinson, Basel, Switzerland) according to a published method (27). Data analysis was performed with Cell Quest software (Becton Dickinson). As further controls, A20.2J were incubated onto the same glass slides with soluble recombinant murine CD95L (kindly obtained from Dr. A. Fontana, University Hospital Zürich) or with medium alone. The experiments were performed three times with several IFN-treated and nontreated patients. To assess CD95L-mediated lysis, ${ }^{51} \mathrm{Cr}$-labeled A20.2J $\left(3 \times 10^{5}\right)$ were seeded onto the cryosections as described above. After $24 \mathrm{~h} \mathrm{su}-$ pernatants $(50 \mu \mathrm{l})$ were harvested and tested for ${ }^{51} \mathrm{Cr}$ release. Details of the ${ }^{51} \mathrm{Cr}$ release assay and calculation of lysis are given elsewhere (21). Two independent experiments were done using cryosections of treated and nontreated patients.

\section{Results}

Identification of apoptosis by in situ end-labeling of fragmented DNA. Biopsy specimens taken from six untreated patients showed that virtually no apoptotic cells were found in BCCs and the small lymphoid infiltrate as identified by the TUNEL (28) technique (Fig. $1 A$ ). In contrast, numerous single apoptotic cells were identified within the tumor masses in patients treated with intralesional IFN-alpha (Fig. $1 B$ ). Interestingly, apoptosis was especially manifest in the center and less at periphery of the tumor nodules (Fig. $1 \mathrm{~B}$, arrows) and the number of apoptotic cells was particularly high in cases showing advanced regression of tumor nests. A small but significant number of apoptotic cells was also manifest in the keratinocytes of the epidermis in the treated as well as untreated patients (data not shown).

Investigation of $B C C$, the surrounding tissue, and the lymphoid infiltrate for CD95 and CD95L by immunohistochemical staining. Biopsy specimens taken from nine interferontreated BCCs revealed a dense dermal lymphoid infiltrate surrounding the regressing tumor nests. The number of cells in the peritumoral infiltrate was highest in biopsy specimens taken from the lesions 2-3 wk after the completion of therapy. Immunohistochemically, the majority of cells in the peritumoral infiltrate were CD4+ T cells (Fig. 1 D). Only few T cells were found within the tumor nodules (arrows). Approximately $10-20 \%$ of the peritumoral infiltrate were CD8+ T cells (data not shown). In contrast, lymphoid-infiltrating cells were only sparsely present in the dermis of patients with untreated BCC

\section{Figure 1 legend (Continued)}

$\mathrm{T}$ cells is found in the dermis of untreated patients. $(D) \mathrm{CD} 4+\mathrm{T}$ cells surround the BCC nests in treated patients, but only few T cells are found within the tumor nodules (arrows). (E) In untreated patients only the keratinocytes in the basal cell layer express CD95 (c), whereas the BCC are CD95-negative. $(F)$ In treated patients a large number of CD95-positive cells are found within the tumor nests $(a)$, in the lymphoid infiltrates surrounding the tumors $(b)$, and in the basal cell layer of the epidermis $(c)$. Epidermic cysts $(d)$ presumably derive from the apoptosis and destruction of the tumor masses. ( $G$ and $H$ ) BCC express CD95L in IFN-alpha-treated $(H)$ as well as untreated patients $(G)$. CD95L-positive cells are predominantly located in the center of the tumor nests $(a)$, some at the periphery of the tumor nests $(b)$, and some in the spinous layers of the epidermis $(c)$. Few CD95L-positive cells are found in the infiltrate preferentially near the blood vessels (arrows). All figures are at an original magnification of 32 with the exception of $D$ and $H$, which are at a magnification of 80 . 

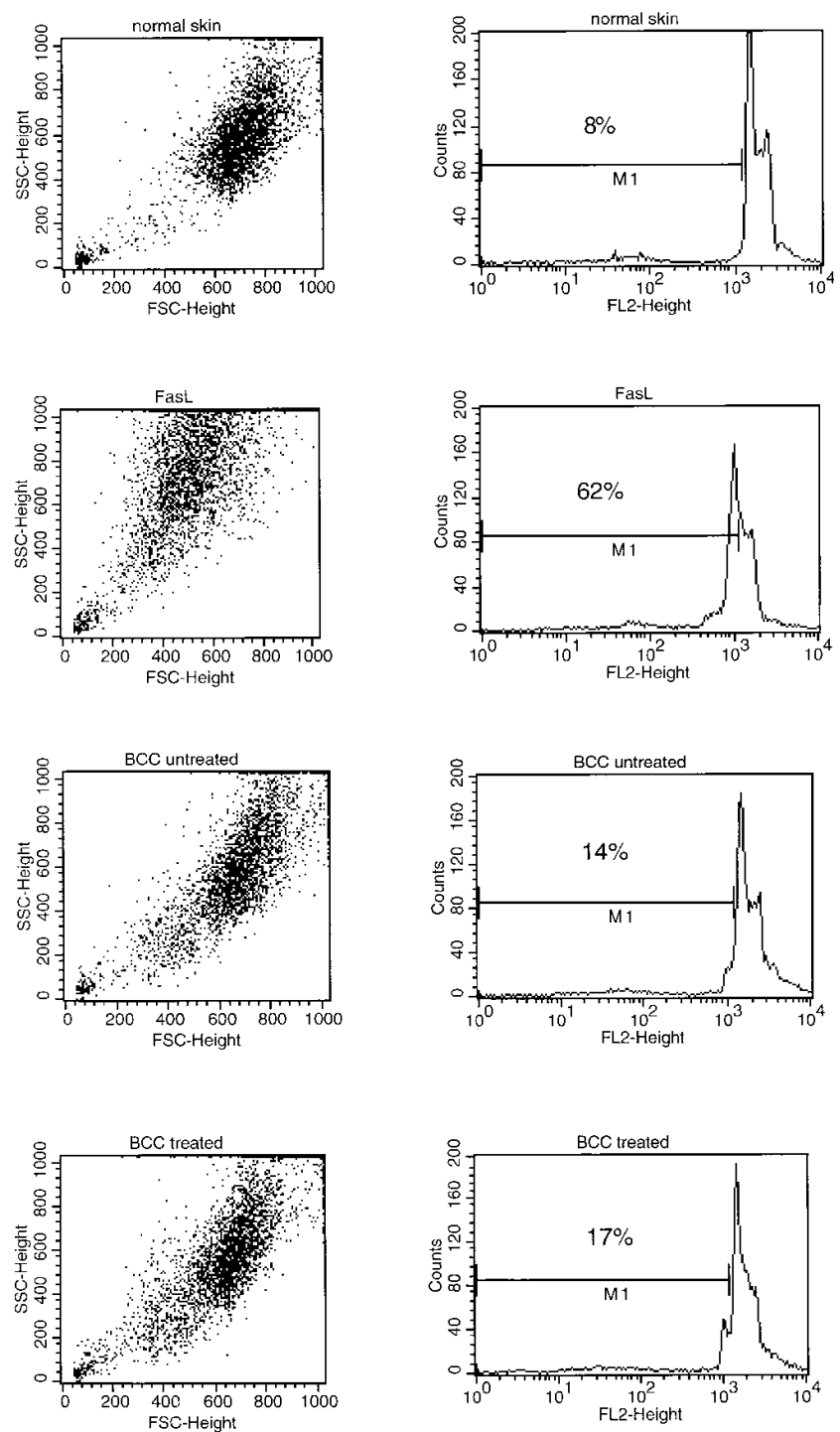

Figure 2. BCC induces apoptosis in CD95-positive A20.2J cells. A20.2J were added onto cryosections of normal skin or BCC from IFN-alpha-treated and untreated patients for $6 \mathrm{~h}$. The cells were then harvested, fixed, and stained with propidium iodide. The rate of apoptosis was analyzed by FACScan. As a control, A20.2J were incubated with soluble CD95L (FasL). The negative control, A20.2J alone, is not shown as no apoptosis was detected. The propidium iodide staining and the percentage of apoptotic cells is given in the histograms. Dot blots note the marked cell shrinking (as a sign of apoptosis) of the A20.2J incubated on treated or untreated BCC compared with normal skin.

(Fig. $1 C$ ), mostly around the blood vessels and at the periphery of tumor nodules. A similar sparse distribution of CD95positive cells was found in the dermis of six untreated patients, whereas the BCC cells were completely CD95-negative (Fig. $1 E$ ). Marked focal inter- and intracellular staining with antiCD95 (Fig. $1 F$ ), however, was seen on the tumor cells in all BCCs treated with intralesional IFN-alpha. In addition, CD95 was strongly expressed on infiltrating lymphoid cells at the periphery of the tumor nests and on those in close contact with the tumor cells (Fig. $1 F$ ). Strong expression of CD95L-positive cells was detected within and around the BCC nodules in all untreated patients (Fig. $1 G$ ). In IFN-alpha-treated patients the BCC tumor nests demonstrated intense CD95L-expression (Fig. $1 H$ ), whereas only few CD95L-expressing cells were found in the lymphoid infiltrates preferentially in the area of blood vessels (arrows). Thus, while the BCC cells of untreated patients constitutively expressed CD95L, the BCC cells of treated patients expressed both CD95L as well as CD95 receptor.

Of interest, basal and suprabasal keratinocytes within the spinous layer strongly stained with anti-CD95 antibody not only in patients with BCC (Fig. 1, $E$ and $F$ ), but also in healthy control subjects (data not shown). In contrast to CD95, CD95L was strongly expressed on keratinocytes in the spinous layer (Fig. $1 G$ ).

$B C C$ express functional $C D 95 L$. To evaluate whether the CD95L expressed by BCC from IFN-alpha-treated and -untreated patients is functional, CD95-positive cells (A20.2J) were incubated on BCC-cryosections, and apoptosis and lysis were measured. FACS analysis after propidium iodide staining showed an increase in the amount of apoptosis of A20.2J added for $6 \mathrm{~h}$ onto BCC from untreated as well as IFN-alphatreated patients (Fig. 2). Normal skin also induced a low amount of apoptosis, which is not surprising since keratinocytes of the spinous layer are CD95L-positive. Moreover, the A20.2J cells incubated on BCC cryosections for $24 \mathrm{~h}$ were strongly lysed as demonstrated in the more sensitive ${ }^{51} \mathrm{Cr}$ release assay (Table I), independent of whether the BCC originated from IFN-alpha-treated or -untreated patients. Normal skin also induced some lysis of A20.2J, again reflecting upon CD95L expression of the keratinocytes.

\section{Discussion}

The results of our study demonstrate that apoptosis is the major mechanism of tumor cell death in regressing BCC after intralesional IFN-alpha treatment. Although numerous factors such as chemotherapeutic agents, ionizing radiation, oncogenes, glucocorticoids, tumor necrosis factor, transforming growth factor beta, and cytolytic T cells are known to induce

Table I. BCC from Treated and Untreated Patients Lyse CD95+ Cells

\begin{tabular}{lcc}
\hline & \multicolumn{2}{c}{${ }^{51} \mathrm{Cr}$ release of A20.2J } \\
\cline { 2 - 3 } & Exp I & Exp II \\
\hline & 12204 & $c p m$ \\
Total release & 3173 & 11915 \\
Spontaneous release & n.t. & 3069 \\
Soluble CD95L & $4839(18 \%)$ & $7819(54 \%)$ \\
Normal skin & $7941(53 \%)$ & $5765(30 \%)$ \\
BCC Pat. A untreated & $6998(42 \%)$ & $9612(74 \%)$ \\
BCC Pat. B treated & $7826(51 \%)$ & $8261(59 \%)$ \\
BCC Pat. C treated & & n.t. \\
\end{tabular}

${ }^{51}$ Cr-labeled A20.2J were added to cryosections of normal skin or BCC obtained from IFN-alpha-treated or -untreated patients. After $24 \mathrm{~h}$ supernatants were harvested and the ${ }^{51} \mathrm{Cr}$ release was determined as $\mathrm{cpm}$ (\% specific release in parenthesis). As control, soluble recombinant CD95L was added to ${ }^{51} \mathrm{Cr}$-labeled A20.2J. n.t., not tested; Pat, patient. 
apoptosis (for review see reference 29), the CD95-CD95L system has been identified as the most important trigger of apoptosis. In this study, we found that the BCCs of untreated patients were strongly CD95L-positive. CD95 was not detectable, confirming the results of other groups $(30,31)$. Thus, $\mathrm{BCC}$ formation in untreated patients may be due to the ability of the tumor cells to lyse attacking CD95-expressing effector T cells via their CD95L. Indeed, CD95L of the BCC proved to be functional and induced in vitro apoptosis and lysis of CD95positive cells such as A20.2J. This strategy resembles the proposed role for $\mathrm{CD} 95 \mathrm{~L}$ in the maintainance of immune privilege in mouse testis and in the anterior chamber of the eye (32, 33 ). Furthermore, our observation is in close agreement with the recent demonstration of constitutive CD95L expression on large granular lymphocytic leukemia cells (34), colon cancer cells (35), melanoma cells (36), hepatocellular carcinoma cells (37), and astrocytoma cells (38). No CD95 expression was detected on colon cancer and melanoma cells, whereas the hepatocellular carcinomas apparently lost CD95 in contrast to normal liver cells (35-37). These tumor types have been suspected to expand by the induction of apoptosis in infiltrating CD95-positive lymphocytes. In our study, however, as the consequence of intralesional treatment with IFN-alpha, BCC cells not only expressed CD95L but also became CD95-positive. Hence, the concomitant expression of both CD95 and CD95L could induce apoptosis within the tumor cells, eventually leading to cell death by suicide or fratricide. A similar mechanism has been reported in $\mathrm{T}$ cell leukemia lines by Friesen et al. (39), who found in in vitro studies that some anticancer drugs (doxorubicin, methotrexate) induced apoptosis via upregulation of the CD95-CD95L system. The question arises whether the infiltrating lymphoid cells also contribute to the destruction of BCC. Indeed, upon IFN-alpha treatment a large lymphoid infiltrate mainly consisting of CD4 $\mathrm{T}$ cells becomes manifest, predominantly around the tumor nests. The majority of these cells infiltrating the dermis, however, express CD95, and only few express CD95L. Although CD4+ CTLs may be able to induce apoptosis in BCC cells via engagement with CD95 (21-23, 25, 40), a major lytic effect of such CD95L-positive CTLs on BCC is rather unlikely for the following reasons: first, only very few $\mathrm{T}$ cells infiltrate the tumor nests, the large majority being located around the BCC (see Fig. $1 D$ ); and second, apoptosis is manifest in the center (see Fig. $1 B$ ) and not at the periphery of the BCC nests, suggesting that tumor destruction starts from inside the nodules, eventually leading to epidermic cysts.

What role does IFN-alpha play in BCC regression? Although IFN-alpha is claimed to inhibit the growth and proliferation of malignant cells by prolonging the length of the cell cycle (11), we propose that its major antitumor property may be based on the recruitment of infiltrating cells and/or upregulation of the CD95-CD95L system. Such an effect may also be responsible for the induction of apoptotic cell death in squamous cell carcinoma cell lines by IFN-alpha (41). Presently, it is unknown whether the IFN-alpha-induced CD95 expression on BCCs is a direct effect of the drug, or is indirectly mediated, e.g., by the lymphoid effector cells. It has been shown that IFN-alpha increases the frequency of IFN-gamma-producing CD4 $+\mathrm{T}$ cells (42), and significantly expands the number of $\mathrm{CD} 4+\mathrm{T}$ cells in the dermis (43). It is also well established that CD95 expression can be induced by interleukin-2 or IFNgamma, or by a combination of IFN-gamma and TNF-alpha
(25). Recent studies showed that IFN-gamma induces a CD95dependent apoptotic process in keratinocytes $(44,45)$. Since CD4+ T cells that are known to be a potent source of such cytokines represent the bulk of the infiltrating peritumoral lymphocytes, it is possible that they upregulate CD95 on BCC cells by secreting these cytokines, and thus indirectly contribute to the CD95L-based cytotoxicity. Presently ongoing in vitro studies will help to better define these unresolved issues.

In summary, our findings reveal the mechanism of BCC regression upon intralesional IFN-alpha treatment. The apoptotic cell death in BCC, as identified by DNA fragmentation and followed by tumor regression, results from specific CD95CD95L interactions. Our study demonstrates that certain tumors can be treated successfully by modulating the CD95CD95L-system.

\section{Acknowledgments}

This work was supported by the Swiss National Science Foundation grant numbers 3100-039331.93 and 3139-06014.95.

\section{References}

1. Greenway, H.T., R.C. Cornell, D.J. Tanner, E. Peets, G.M. Bordin, and C. Nagi. 1986. Treatment of basal cell carcinoma with intralesional interferon. J. Am. Acad. Dermatol. 15:437-443.

2. Buechner, S.A. 1991. Intralesional interferon alfa-2b in the treatment of basal cell carcinoma. J. Am. Acad. Dermatol. 24:731-734.

3. Cornell, R.C., H.T. Greenway, S.B. Tucker, L. Edwards, S. Ashworth, J.C. Vance, D.J. Tanner, E.L. Tylor, K.A. Smiles, and E.A. Peets. 1990. Intralesional interferon therapy for basal cell carcinoma. J. Am. Acad. Dermatol. 23: 694-700.

4. Wickramasinghe, L., T.C. Hindson, and H. Wacks. 1989. Treatment of neoplastic skin lesions with intralesional interferon. J. Am. Acad. Dermatol. 20: 71-74.

5. Bottomley, W.W., and K. Keczkes. 1991. Treatment of basal cell carcinomas with intralesional recombinant interferon-alfa-2b.J. Dermatol. Treat. 2:15-16.

6. Thestrup-Pedersen, K., I.E. Jacobsen, and G. Frentz. 1990. Intralesional interferon-alpha $2 \mathrm{~b}$ treatment of basal cell carcinoma. Acta Dermato-Venereol. 70:512-514.

7. Grob, J.J., A.M. Collet, M.H. Munoz, and J.J. Bonerandi. 1988. Treatment of large basal cell carcinomas with intralesional interferon alpha-2a. Lancet. 1:878-879.

8. Buechner, S.A., S. Lautenschlager, P. Schiller, P. Itin, P. Bigliardi, J. Izakovic, B. Yilmaz, D. Müller, and S. Courvoisier. 1995. Treatment of basal cell carcinomas with intralesional interferon alfa-2b. Dermatology (Basel). 191:173-174.

9. Hunt, M.J., G.M. Halliday, D. Weedon, B.E. Cooke, and R.S. Barnetson. 1994. Regression in basal cell carcinoma: an immunohistochemical analysis. $\mathrm{Br}$. J. Dermatol. 130:1-8.

10. Chimenti, S., K. Peris, S. Di Cristofaro, M.C. Fargnoli, and G. Torlone. 1995. Use of recombinant interferon alfa-2b in the treatment of basal cell carcinoma. Dermatology (Basel). 190:214-217.

11. Gresser, I. 1990. Biologic effects of interferons. J. Investig. Dermatol. 95 : $66 \mathrm{~S}-71 \mathrm{~S}$.

12. Ucar, R., M. Sanwo, K. Ucar, and G. Beall. 1995. Interferons: their role in clinical practice. Ann. Allergy. 75:377-386.

13. Knop, J. 1990. Immunologic effects of interferon. J. Investig. Dermatol. 95:72S-74S

14. Mozzanica, N., A. Cattaneo, V. Boneschi, L. Brambilla, E. Melotti, and A.F. Finzi. 1990. Immunohistological evaluation of basal cell carcinoma immunoinfiltrate during intralesional treatment with alpha-2-interferon. Arch. Dermatol. Res. 282:311-317.

15. Williams, G.T. 1994. Apoptosis in the immune system. J. Pathol. 173:1-4. 16. Ueda, N., and S.V. Shah. 1994. Apoptosis. J. Lab. Clin. Med. 124:169-177.

17. Golstein, P., D.M. Ojcius, and J.D.E. Young. 1991. Cell death mechanisms and the immune system. Immunol. Rev. 121:29-65.

18. Wyllie, A.H., J.F.R. Kerr, and A.R. Currie. 1980. Cell death: the significance of apoptosis. Int. Rev. Cytol. 68:251-306.

19. Buja, L.M., M.L. Eigenbrodt, and E.H. Eigenbrodt. 1993. Apoptosis and necrosis. Basic types and mechanisms of cell death. Arch. Pathol. Lab. Med. 117:1208-1214.

20. Kerr, J.F.R., C.M. Winterford, and B.V. Harmon. 1994. Apoptosis. Its significance in cancer and cancer therapy. Cancer. 73:2013-2026.

21. Stalder, T., S.H. Hahn, and P. Erb. 1994. Fas antigen is the major target 
molecule for CD4+ T-cell-mediated cytotoxicity. J. Immunol. 152:1127-1133.

22. Hanabuchi, S., M. Koyanagi, A. Kawasaki, N. Shinohara, A. Matsuzawa, Y. Nishimura, Y. Kobayashi, S. Yonehara, H. Yagita, and K. Okumura. 1994. Fas and its ligand in a general mechanism of T-cell-mediated cytotoxicity. Proc. Natl. Acad. Sci.USA. 91:4930-4934.

23. Ju, S.T., H.L. Cui, D.J. Panka, R. Ettinger, and A. Marshakrothstein. 1994. Participation of target Fas protein in apoptosis pathway induced by CD4(+) Th1 and CD8(+) cytotoxic T cells. Proc. Natl. Acad. Sci. USA. 91: 4185-4189.

24. Hahn, S., R. Gehri, and P. Erb. 1995. Mechanism and biological significance of CD4-mediated cytotoxicity. Immunol. Rev. 146:57-79.

25. Nagata, S., and P. Golstein. 1995. The Fas death factor. Science. 267: $1449-1456$

26. Tanaka, M., T. Suda, T. Takahashi, and S. Nagata. 1995. Expression of the functional soluble form of human Fas ligand in activated lymphocytes. EMBO (Eur. Mol. Biol. Organ) J. 14:1129-1135.

27. Nicoletti, I., G. Migliorati, M.C. Pagliacci, F. Grignani, and C. Riccardi. 1991. A rapid and simple method for measuring thymocyte apoptosis by propidium iodide staining and flow cytometry. J. Immunol. Methods. 139:271-279.

28. Gavrieli, Y., Y. Sherman, and S. Ben-Sasson. 1992. Identification of programmed cell death in situ via specific labeling of nuclear DNA fragmentation. J. Cell Biol. 119:493-501.

29. Thompson, C.B. 1995. Apoptosis in the pathogenesis and treatment of disease. Science. 267:1456-1462.

30. Leithäuser, F., J. Dhein, G. Mechtersheimer, K. Koretz, S. Brüderlein, C. Henne, A. Schmidt, K.M. Debatin, P.H. Krammer, and P. Möller. 1993. Constitutive and induced expression of Apo-1, a new member of the nerve growth factor/tumor necrosis factor receptor superfamily, in normal and neoplastic cells. Lab. Invest. 69:415-429.

31. Oishi, M., K. Maeda, and S. Sugiyama. 1994. Distribution of apoptosismediating Fas antigen in human skin and effects of anti-Fas monoclonal antibody on human epidermal keratinocyte squamous cell carcinoma cell lines. Arch. Dermatol. Res. 286:396-407.

32. Bellgrau, D., D. Gold, H. Selawry, J. Moore, A. Franzusoff, and R.C. Duke. 1995. A role for CD95 ligand in preventing graft rejection. Nature. 377: 630-632.

33. Griffith, T.S., T. Brunner, S.M. Fletcher, D.R. Green, and T.A. Ferguson. 1995. Fas ligand-induced apoptosis as a mechanism of immune privilege. Science. 270:1189-1192.
34. Tanaka, M., T. Suda, K. Haze, N. Nakamura, K. Sato, F. Kimura, K. Motoyoshi, M. Mizuki, S. Tagawa, S. Ohga, et al. 1996. Fas ligand in human serum. Nat. Med. 2:317-322.

35. O'Connell, J., G.C. O'Sullivan, J.K. Collins, and F. Shanahan. 1996. The Fas counterattack: Fas-mediated $\mathrm{T}$ cell killing by colon cancer cells expressing Fas ligand. J. Exp. Med. 184:1075-1082.

36. Hahne, M., D. Rimoldi, M. Schröter, P. Romero, M. Schreier, L.E. French, P. Schneider, T. Bornand, A. Fontana, D. Lienard, et al. 1996. Melanoma cell expression of Fas (Apo-1/CD95) ligand: implication for tumor immune escape. Science. 274:1363-1366.

37. Strand, S., W.J. Hofmann, H. Hug, M. Müller, G. Otto, D. Strand, S.M. Mariani, W. Stremmel, P.H. Krammer, and P.R. Galle. 1996. Lymphocyte apoptosis induced by CD95 (Apo-1/Fas) ligand-expressing tumor cells-A mechanism of immune evasion. Nat. Med. 2:1361-1366.

38. Saas, P., P.R. Walker, M. Hahne, A.L. Quiquerez, V. Schnuriger, G. Perrin, L. French, E.G. VanMeir, N. Detribolet, J. Tschopp, and P.Y. Dietrich. 1997. Fas ligand expression by astrocytoma in vivo: Maintaining immune privilege in the brain? J. Clin. Invest. 99:1173-1178.

39. Friesen, C., I. Herr, P.H. Krammer, and K.M. Debatin. 1996. Involvement of the CD95 (APO-1/Fas) receptor/ligand system in drug-induced apoptosis in leukemia cells. Nat. Med. 2:574-577.

40. Lenardo, M.J. 1996. Fas and the art of lymphocyte maintenance. J. Exp. Med. 183:721-724

41. Rodriguez-Villanueva, J., and T.J. McDonnell. 1995. Induction of apoptotic cell death in non-melanoma skin cancer by interferon-alpha. Int. J. Cancer. 61:110-114.

42. Brinkmann, V., T. Geiger, S. Alkan, and C.H. Heusser. 1993. Interferon-alpha increases the frequency of interferon-gamma-producing human CD4+ T-cells. J. Exp. Med. 178:1655-1663.

43. Tong, Y., and S.B. Tucker. 1993. Normal skin lymphocytic and Langerhans' cell responses to intradermal interferon alpha-2b injections. Am. J. Med. Sci. 306:23-27.

44. Sayama, K., S. Yonehara, Y. Watanabe, and Y. Miki. 1994. Expression of Fas antigen on keratinocytes in vivo and induction of apoptosis in cultured keratinocytes. J. Investig. Dermatol. 103:330-334.

45. Takahashi, H., H. Kobayashi, Y. Hashimoto, S. Matsuo, and H. Iizuka 1995. Interferon-gamma-dependent stimulation of Fas antigen in SV40-transformed human keratinocytes: modulation of the apoptotic process by protein kinase C. J. Investig. Dermatol. 105:810-815. 